\title{
Zdrowie publiczne w Polsce - problemy i wyzwania
}

Public health in Poland - problems and challenges: This article provides an overview of the problems and challenges that arise in the field of public health in Poland. In the first part it discusses general issues, i.e. the definition of public health, its essential operations according to WHO and core services, as well as public spending on preventive services. Next, it examines some aspects of the public health practice, with special attention given to planning, evaluation and good practices, as well as recommendations for public health capacity improvements. The author claims that it is necessary to standardize the terminology and develop tools, standards and work protocols regarding public health.

Słowa kluczowe: $\quad$ zdrowie publiczne w Polsce, praktyka zdrowia publicznego, ewaluacja programów, rozwój potencjału

Keywords: public health in Poland, practice of public health, programme evaluation, capacity building

* Doktor hab. nauk medycznych, profesor w Szkole Zdrowia Publicznego Centrum Medycznego Kształcenia Podyplomowego; e-mail: dorota.cianciara@cmkp.edu.pl.

\section{Wstęp}

W ostatnich dekadach w krajach wysoko rozwiniętych obserwowano znaczne wydłużenie oczekiwanego czasu życia, co było głównie efektem kontroli chorób zakaźnych, lepszych warunków sanitarnych, poprawy w zakresie bezpieczeństwa żywności, jakości żywności i dostępu do niej, poprawy bezpieczeństwa ruchu drogowego oraz innych działań profilaktycznych realizowanych na poziomie populacji, a więc działań zdrowia publicznego, a nie stricte leczniczych.

Jaki udział w tym sukcesie może mieć medycyna naprawcza? Odpowiedzią na to pytanie są różne szacunki, szczególnie popularne w USA, dotyczące skali wpływu lecznictwa na stan zdrowia populacji. Dla przykładu: Julius Richmond podawał, że analiza 10 wiodących przyczyn zgonów w populacji USA w $1976 \mathrm{r}$. uprawnia do postawienia tezy, że zaledwie $10 \%$ zgonów było związanych z nie- 
odpowiednią opieką medyczną ${ }^{1}$, Alvin Tarlov twierdził, że opieka ta odpowiada za ok. $20 \%$ stanu zdrowia populacji ${ }^{2}$, a John Bunker uważał, że co najwyżej połowa sukcesu w wydłużeniu życia mogła być wynikiem działań medycyny naprawczej ${ }^{3}$. Istotny udział medycyny w zapobieganiu zgonom mogą podważyć również najnowsze ustalenia, które w sierpniu 2018 r. opublikowali Jessica Ho i współpracownicy. Otóż w większości krajów rozwiniętych odnotowano spadek oczekiwanej długości życia w latach 2014-2015. Przyczyny tej sytuacji nie są wyjaśnione i zjawisko musi być bacznie obserwowane. Być może jesteśmy świadkami trwałego odwrócenia korzystnej tendencji wydłużania życia, ponieważ także GUS podaje, że: $W 2017$ r. w Polsce mężczyźni żyli przeciętnie 74,0 lat, natomiast kobiety 81,8 lat. Przeciętne trwanie życia noworodka ptci męskiej zwiększyło się, a żeńskiej zmniejszyło się w stosunku do roku poprzedniego o 0,1 roku ${ }^{5}$.

Poza działaniami leczniczymi zdrowie zależy od czynników genetycznych, zachowań ludzkich oraz uwarunkowań środowiskowych, społecznych i ekonomicznych. Według A. Tarlova decydujący wpływ na zdrowie mają te ostatnie uwarunkowania, czyli społeczno-ekonomiczne, bowiem decydują o stanie zdrowia populacji w ok. 55\%. Niezależnie od tego, jak w szczegółach wygląda kwantyfikacja roli poszczególnych uwarunkowań zdrowia, wszyscy autorzy są zgodni - medycyna nie jest główną siłą sprawczą zdrowia. Otwiera to szerokie pole do działalności profilaktycznej, a więc zdrowia publicznego.

Deklaratywnie, owszem, twierdzi się, że lepiej zapobiegać niż leczyć, jednak w potocznym myśleniu i realiach systemu ochrony zdrowia rażąco przecenia się znaczenie lecznictwa i deprecjonuje zdrowie publiczne. Wyjaśnień tego stanu jest wiele i warto tu zwrócić uwagę na jedno z nich. Otóż w 1981 r. Goeffrey Rose opisał tzw. paradoks profilaktyki, który polega na tym, że działania, które przynoszą ogromne korzyści dużym grupom, takie jak profilaktyka chorób realizowana na poziomie populacyjnym, oferują niewiele poszczególnym osobom, toteż nie są przez te osoby cenione ${ }^{6}$. W efekcie obowiązek używania pasów

${ }^{1}$ Healthy People: The Surgeon General's Report on Health Promotion and Disease Prevention, U.S. Department of Health, Education, and Welfare, United States Public Health Service 1979, rozdz. 1, s. 1-9.

2 A.R. Tarlov, Public policy frameworks for improving population health, „Annals of the New York Academy of Sciences" 1999, t. 896, s. 281-293.

3 J.P. Bunker, The role of medical care in contributing to health improvements within societies, „International Journal of Epidemiology” 2001, t. 30, nr 6, s. 1260-1263.

${ }^{4}$ J.Y. Ho, A.S. Hendi, Recent trends in life expectancy across high income countries: retrospective observational study, „BMJ” 2018, 362:k2562, https://doi.org/10.1136/bmj.k2562 [dostęp: 23 września 2018 r.].

${ }^{5}$ GUS, Trwanie życia w 2017 r., Warszawa 2018, s. 13.

${ }^{6}$ G. Rose, Strategy of prevention: lessons from cardiovascular disease, „British Medical Journal (Clinical Research Ed.)" 1981, t. 282, nr 6279, s. 1847-1851. 
bezpieczeństwa w samochodzie czy szczepienia ochronne mają małą wartość w odbiorze społecznym, chociaż uratowały miliony istnień. Paradoks ten może prowadzić do niedostatecznego finansowania działań profilaktycznych. Zaś przy niskich nakładach na profilaktykę należy oczekiwać większej liczby zachorowań, większego popytu na świadczenia lecznicze i rosnących kosztów opieki medycznej. W efekcie priorytetem przy alokacji środków finansowych w systemie ochrony zdrowia staje się lecznictwo i coraz mniej pieniędzy przeznacza się na zapobieganie. I błędne koło zamyka się.

Obecnie panuje globalny trend ożywienia oraz wzmocnienia zdrowia publicznego i tworzy się plany zwiększania jego potencjału wykonawczego, w tym także w Regionie Europejskim Światowej Organizacji Zdrowia (WHO) ${ }^{7}$, który obejmuje 53 kraje. Wynika to zarówno z przyczyn pragmatycznych, takich jak wyzwania wynikające z przemian demograficznych i rosnące potrzeby zdrowotne (przede wszystkim na skutek starzenia się społeczeństw, rozpowszechnienia chorób, nowych zagrożeń zdrowotnych i wzrostu świadomości zdrowotnej) oraz chęć obniżenia kosztów opieki zdrowotnej, jak również ideowych, czyli dążenia do sprawiedliwości i równości w zdrowiu.

Plan wzmocnienia zdrowia publicznego w Regionie Europejskim WHO wyznacza kierunki działań dla państw członkowskich, w tym dla Polski. Realizacja planu rozwoju potencjału zdrowia publicznego na poziomie krajowym wymaga nie tylko zaangażowania politycznego, zarządzania procesem, partnerstwa i komunikacji, innowacji społecznych czy wsparcia technicznego, ale przede wszystkim doceniania zdrowia publicznego i pełnej świadomości jego atrybutów. Plan WHO wpisuje się w szerszy nurt umiędzynarodowienia spraw związanych ze zdrowiem oraz rozwoju nowych gałęzi zdrowia publicznego, czyli tzw. zdrowia międzynarodowego i zdrowia globalnego ${ }^{8}$. Polega to na wspólnym rozumieniu uwarunkowań zdrowia, a zwłaszcza na połączeniu wysiłków na rzecz zdrowia i zrównoważonego rozwoju oraz równości w zdrowiu w krajach innych niż własny (pomaganie innym narodom - zdrowie międzynarodowe) lub w skali ponadnarodowej (równość w zdrowiu między narodami - zdrowie globalne). W tym nurcie na zagranicznych uczelniach powstają nowe kierunki studiów, w wielu instytucjach i organizacjach tworzone są nowe stanowiska pracy i rozwija się międzynarodowa dyplomacja zdrowotna. Z tej perspektywy koniecznością jest takie rozwijanie potencjału zdrowia publicznego w Polsce, które uwzględniałoby bieżące tendencje i światowy dorobek tej dziedziny, najlepsze doświadczenia oraz dowody naukowe.

7 WHO, European Action Plan for Strengthening Public Health Capacities and Services, WHO Regional Office for Europe, Copenhagen 2012.

8 J.P. Koplan i in., for the Consortium of Universities for Global Health Executive Board, Towards a common definition of global health, „Lancet” 2009, t. 373, nr 9679, s. 1993-1995, https://doi.org/10.1016/S0140-6736(09)60332-9 [dostęp: 22 listopada 2018 r.]. 
Celem tego opracowania jest omówienie problemów i wyzwań stojących przed zdrowiem publicznym w Polsce w aspekcie atrybutów tej dziedziny. W pierwszej części (cztery pierwsze rozdziały) skoncentrowano się na zagadnieniach ogólnych: definicji zdrowia publicznego, jego podstawowych funkcjach oraz kluczowych świadczeniach, a także publicznych wydatkach na te działania. Druga część (następne dwa rozdziały) poświęcona jest zagadnieniom dotyczącym praktycznej realizacji świadczeń zdrowia publicznego, a zwłaszcza programom zdrowotnym i dobrym praktykom, oraz zaleceniom co do poprawy działań w tej dziedzinie w Polsce. Treści większości rozdziałów starano się przedstawić w taki sposób, aby najpierw zaprezentować międzynarodowe tło i kontekst sytuacji, a następie odnieść się do sytuacji w Polsce. W opracowaniu tym nie ma możliwości, aby przedstawić wszystkie problemy zdrowia publicznego ani też omówić całość zasygnalizowanych zagadnień.

\section{Definicje zdrowia publicznego}

Spośród wielu istniejących w piśmiennictwie definicji zdrowia publicznego w Regionie Europejskim WHO przyjęto następującą: zdrowie publiczne jest nauką i sztukg zapobiegania chorobie, wydłużania życia oraz promowania zdrowia za pomoca zorganizowanych wysiłków społeczeństwa. Definicja ta została sformułowana przez Donalda Achesona w 1988 r. ${ }^{9}$ i jako objaśnienie syntetyczne oraz proste zyskała szeroką aprobatę różnych gremiów.

Od 1986 r. w piśmiennictwie naukowym używano terminu „nowe zdrowie publiczne”, który Theodore Tulchinsky opisał jako współczesne zastosowanie szerokiej gamy działań charakterystycznych dla systemów naukowych opartych na dowodach, technologicznych i zarządczych, w celu poprawy zdrowia jednostek i populacji ${ }^{10}$. Don Nutbeam podkreślał, że wprowadzenie tego terminu służyło temu, aby zaakcentować względnie nowy wówczas sposób działania zdrowia publicznego ${ }^{11}$, tj. na podstawie społeczno-środowiskowego (ekologicznego) modelu zdrowia, zainicjowanego ekologiczną teorią rozwoju człowieka według Uriego Bronfenbrennera. Ekologiczny model zdrowia, zgodnie $z$ wieloma dowodami epidemiologicznymi, stanowi, że zasadniczy wpływ na sytuację zdrowotną ludności mają czynniki społeczne i warunki życia, a ich nierówna i niesprawiedliwa dystrybucja prowadzi do nierówności w zdrowiu. W przeciwieństwie do innych modeli zdrowia, tj. tradycyjnego biomedyczno-patologicznego oraz behawioralnego z lat 70-80. XX wieku, model ekologiczny

9 D. Acheson, Public Health in England: The Report of the Committee of Inquiry into the Future Development of the Public Health Function, H.M. Stationery Office, London 1988.

10 T.H. Tulchinsky, E.A. Varavikova, What is the „New Public Health”?, „Public Health Reviews" 2010, t. 32, nr 1, s. 25-53, https://doi.org/10.1007/BF03391592 [dostęp: 23 września 2018 r.].

11 D. Nutbeam, Health promotion glossary, „Health Promotion International”1986, t. 1, nr 1, s. 113-127, https://doi.org/10.1093/heapro/1.1.113 [dostęp: 23 września 2018 r.]. 
wskazuje, że do poprawy zdrowia konieczne są działania na poziomie jednostkowym, poziomie interpersonalnym, działania na poziomie instytucji i społeczności, a także polityki publicznej. Jednak nie było to żadne novum, ponieważ już w 1851 r. Rudolf Virchow pisał: Choroba nie jest czymś osobistym i szczególnym, ale tylko oznaka życia w zmienionych warunkach (...). Każda powszechna choroba $w$ społeczeństwie, czy to psychiczna, czy fizyczna, pokazuje nam życie ludności w nienormalnych warunkach $i$ wszystko, co musimy zrobić, to rozpoznać tę nieprawidłowość i zasygnalizować ją mężowi stanu, aby mógł ją zlikwidować12.

W Polsce termin „zdrowie publiczne” przyjął się stosunkowo niedawno, bowiem dopiero w okresie przed akcesją do Unii Europejskiej, co wynikało z wprowadzenia dorobku Wspólnoty do krajowego systemu prawnego. Wcześniej używano innych określeń, pokrewnych, chociaż nie całkiem zgodnych z domeną zdrowia publicznego, takich jak higiena, higiena społeczna, działania sanitarno-epidemiologiczne, medycyna społeczna czy medycyna zapobiegawcza.

I tak na przykład, medycyna społeczna wywodzi się z XIX-wiecznej tradycji europejskiej, szczególnie francuskiej, niemieckiej i brytyjskiej. Jej odpowiednikiem, zwłaszcza na gruncie amerykańskim i kanadyjskim, jest tzw. medycyna społeczności. Medycyna społeczna jest działem medycyny, który zajmuje się badaniem związków między stanem zdrowia ludności a warunkami życia społecznego oraz wykorzystaniem tej wiedzy w praktyce lekarskiej. Medycyna zapobiegawcza rozwinęła się mniej więcej w latach 40 . XX wieku i powstała jako przeciwwaga dla zdrowia publicznego, które koncentrowało się wówczas li tylko na zwalczaniu chorób zakaźnych. Miało to służyć poszerzeniu zainteresowania o choroby przewlekłe. W Polsce przykładem medycyny zapobiegawczej jest służba medycyny pracy.

W ostatnich latach w USA toczy się dyskusja, czy medycyna zapobiegawcza jest w ogóle medycyną, skoro nie zajmuje się leczeniem, a profilaktyką. Zdania są podzielone, jednak przeważa pogląd, że jest to bardziej gałąź medycyny niż część zdrowia publicznego. W USA coraz bardziej popularna jest tzw. medycyna stylu życia, czyli gałąź medycyny klinicznej, która jest ukierunkowana na stosowanie terapii opartych na stylu życia i zmianie zachowań pacjentów ${ }^{13}$.

W Kanadzie istnieje natomiast specjalizacja lekarska w łącznej dziedzinie zdrowia publicznego oraz medycyny zapobiegawczej, co sugerowałoby, że według Royal College of Physicians medycyna zapobiegawcza jest postrzegana jako nieodłączny element zdrowia publicznego ${ }^{14}$.

12 R. Virchow, Report on the typhus epidemic in Upper Silesia, „Archiv für Pathologishe Anatomie und Physiologie und für Klinische Medizin” 1848, t. II, nr 1-2 [za:] „Social Medicine" 2006, t. 1, nr 1, 28-82.

${ }_{13}$ L. Lianov, M. Johnson, Physician competencies for prescribing lifestyle medicine, „JAMA” 2010, t. 304, nr 2, s. 202-203.

${ }^{14}$ Royal College of Physicians, Objectives of training in the specialty of public health and preventive medicine, 2014, http://www.royalcollege.ca/cs/groups/public/documents/document/y2vk/mdaw/ edisp/tztest3rcpsced000887.pdf [dostęp: 23 września 2018 r.]. 
Omówione przykłady pokazują, że nawet w krajach, w których zdrowie publiczne ma długą i silną tradycję, istnieją różne nurty działalności o podobnym do zdrowia publicznego charakterze, a więc także rozbieżności dotyczące tożsamości tej dziedziny. Nie inaczej jest w Polsce, $\mathrm{z}$ tym jednak, że skala rozbieżności wydaje się tu znacznie większa. Należy też zauważyć, że w Polsce nazbyt często używa się terminu „zdrowie publiczne” w odniesieniu do opisu sytuacji zdrowotnej ludności, zdrowotności publicznej, czego przykładem może być uzasadnienie do projektu ustawy o zdrowiu publicznym ${ }^{15}$. Biorąc pod uwagę stosunkowo krótki w Polsce rodowód zdrowia publicznego jako dziedziny naukowej i obszaru działalności praktycznej, należałoby zachować porządek terminologiczny i unikać użycia tego określenia w stosunku do stanu zdrowia zbiorowości. Nie jest to jednak jedyny problem semantyczny w tej dziedzinie, co zostanie opisane także w dalszej części artykułu. Problemy te pokazują, że istnieje pilna potrzeba opracowania leksykonu zdrowia publicznego.

\section{Funkcje zdrowia publicznego}

Niemal 100 państw na świecie posiada listy podstawowych funkcji zdrowia publicznego, odpowiednią dla swoich potrzeb i kontekstu organizacyjnego, czyli w efekcie dysponuje drogowskazem do rozwoju potencjału wykonawczego. W liczbie tej mieszczą się poszczególne państwa, jak np. USA, Australia, Wielka Brytania, oraz regiony WHO, jak np. PanAmerican Health Organization czy Region Europejski.

W Regionie Europejskim WHO przyjęto, że podstawowe funkcje (essential public health operations, EPHOs) obejmują 10 obszarów, z których jedna połowa stanowi trzon aktywności, a druga dotyczy funkcji umożliwiających i wspierających działania (tabela 1 ).

W Polsce nie podjęto nigdy próby wspólnego ustalenia funkcji dla krajowego zdrowia publicznego, chociaż istniały autorskie próby ich określenia przedstawione na przykład przez Jerzego Leowskiego ${ }^{16} \mathrm{czy} \mathrm{Jana} \mathrm{Nosko}{ }^{17}$. Polska jest jednak sygnatariuszem rezolucji WHO dotyczącej przyjęcia EPHOs oraz wzmocnienia potencjału zdrowia publicznego w Regionie. Jednym z efektów tej umowy jest to, że w $2015 \mathrm{r}$. w naszym kraju wykonano dwie analizy organizacji i funkcjonowania systemu zdrowia publicznego przy pomocy bardzo drobiazgowego narzędzia, które zaproponowała $\mathrm{WHO}^{18}$. Wyniki tych analiz

15 Projekt ustawy o zdrowiu publicznym. Uzgodnienia, 28 marca 2015 r., https://legislacja.rcl. gov.pl/docs//2/12270850/12281752/12281753/dokument156531.pdf [dostęp: 23 września 2018 r.].

16 J. Leowski, Funkcje zdrowia publicznego, „Zdrowie Publiczne” 2001, t. 111, s. 382-386.

17 J. Nosko, O potrzebie ustawy o zdrowiu publicznym, „Zdrowie Publiczne” 2001, t. 111, s. $75-80$.

$18 \mathrm{WHO}$, Self-assessment tool for the evaluation of essential public health operations in the WHO European Region, WHO Regional Office for Europe, Copenhagen 2015. 
Tabela 1. Podstawowe funkcje zdrowia publicznego przyjęte w Regionie Europejskim WHO

\begin{tabular}{|c|c|c|l|}
\hline \multicolumn{2}{|c|}{ Funkcje kluczowe } & \multicolumn{2}{c|}{ Funkcje ułatwiające } \\
\hline \multicolumn{2}{|c|}{ Zwiad epidemiologiczny } & 6 & $\begin{array}{l}\text { Zapewnienie zarządzania (gospodarowania) } \\
\text { zdrowiem }\end{array}$ \\
\hline 1 & Nadzór nad zdrowiem i dobrostanem & 7 & $\begin{array}{l}\text { Zapewnienie kompetentnej kadry zdrowia } \\
\text { publicznego }\end{array}$ \\
\hline 2 & $\begin{array}{l}\text { Monitorowanie zagrożeń dla zdrowia i sytuacji } \\
\text { kryzysowych oraz reagowanie na nie }\end{array}$ & 8 & $\begin{array}{l}\text { Zapewnienie struktury organizacyjnej i finan- } \\
\text { sowania }\end{array}$ \\
\hline \multicolumn{2}{|c|}{ Świadczenia zdrowia publicznego } & 9 & $\begin{array}{l}\text { Komunikacja, rzecznictwo zdrowotne* i mobili- } \\
\text { zacja społeczna na rzecz zdrowia }\end{array}$ \\
\hline 3 & $\begin{array}{l}\text { Ochrona zdrowia, w tym tzw. zdrowie środowi- } \\
\text { skowe, pracujących, bezpieczeństwo żywności }\end{array}$ & 10 & $\begin{array}{l}\text { Rozwój badań w dziedzinie zdrowia publicznego } \\
\text { dla potrzeb polityki oraz praktyki }\end{array}$ \\
\hline 4 & $\begin{array}{l}\text { Promocja zdrowia, w tym działania dotyczące } \\
\text { społecznych uwarunkowań zdrowia oraz nie- } \\
\text { równości w zdrowiu }\end{array}$ & \multicolumn{2}{|c}{} \\
\hline 5 & $\begin{array}{l}\text { Zapobieganie chorobom, w tym wczesne ich } \\
\text { wykrywanie }\end{array}$ \\
\cline { 1 - 2 }
\end{tabular}

* Rzecznictwo zdrowotne to wspólne działania jednostek i społeczności, zaplanowane w celu uzyskania społecznej akceptacji dla rozwiązań prozdrowotnych, a także szerokiego zaangażowania i zobowiązania politycznego; zob. D. Nutbeam, Health promotion glossary, „Health Promotion International” 1986, t. 1, nr 1, s. 113-127, https://doi.org/10.1093/heapro/1.1.113 [dostęp: 23 września 2018 r.].

Źródło: WHO, European Action Plan for Strengthening Public Health Capacities and Services, WHO Regional Office for Europe, Copenhagen 2012.

pokazały, że najlepszą ocenę uzyskały funkcje 1, 3 oraz 6, ale żadna z nich nie uzyskała oceny maksymalnej. Sformułowano przy tym bardzo liczne zalecenia dla poprawy działań. Zalecenia te zostaną przedstawione w ostatnim rozdziale pt. „Rekomendacje dotyczące poprawy funkcjonowania zdrowia publicznego w Polsce".

\section{Charakterystyka świadczeń zdrowia publicznego}

Do świadczeń zdrowia publicznego należą: ochrona zdrowia, zapobieganie chorobom oraz promocja zdrowia realizowane w skali populacji (EPHO 3-4). Świadczenia takie stanowią istotę i trzon działalności zdrowia publicznego. Przebiegają pod postacią polityk, regulacji prawnych lub programów zdrowotnych. Są to takie działania zdrowia publicznego, z którymi bezpośrednią styczność ma każdy obywatel, nawet jeśli nie wie, jaki jest rodowód tych działań, i każdy w jakiejś mierze z nich korzysta i może odnosić korzyści. W zwiększeniu skuteczności świadczeń zdrowia publicznego można upatrywać szansy na wzrost zainteresowania tą dziedziną, na kreowanie jej wizerunku, a także na wzrost poziomu finansowania. Realizacja pozostałych funkcji zdrowia publicznego (EPHO 1, 2, 6-10) jest stosunkowo mało widoczna dla obywateli, jednak jest niezbędna do tego, aby skutecznie wykonać świadczenia. 


\section{Ochrona zdrowia}

Ochrona zdrowia w rozumieniu WHO obejmuje liczne kwestie, między innymi kontrolę epidemii chorób zakaźnych i antybiotykooporności, zmianę klimatu i zrównoważony rozwój, ryzyko środowiskowe, warunki sanitarne i warunki pracy czy bezpieczeństwo żywności. Zagadnienia te, w tym kwestia powszechnego i równego dostępu do gwarantowanych świadczeń opieki zdrowotnej oraz zapewnienie bezpieczeństwa środowiskowego, zostały uregulowane w licznych aktach prawnych i poddane nadzorowi oraz kontroli różnych organów administracji publicznej, co komplikuje proces koordynacji wysiłków. Omówienie tych wszystkich zagadnień wymagałoby osobnego opracowania.

\section{Profilaktyka chorób}

Według WHO profilaktyka chorób (zapobieganie chorobom) obejmuje działania skierowane nie tylko na zapobieganie wystąpieniu choroby (jak np. szczepienia, kontrola wektorów przenoszących choroby lub działalność antytytoniowa), ale również na zahamowanie postępu choroby, a także ograniczanie jej skutków, kiedy już wystąpi ${ }^{19}$.

Zwyczajowo wśród lekarzy profilaktykę chorób dzieli się na pierwotną, wtórną oraz trzeciorzędową. Podział ten wynika z historii naturalnej choroby. Profilaktyka pierwotna dąży do zapobieżenia chorobie, wtórna polega na wczesnym jej wykrywaniu i w efekcie wczesnym podjęciu leczenia, a trzeciorzędowa na leczeniu i rehabilitacji. Jednak wskazany podział profilaktyki nie jest jedyny i równolegle w użyciu są podejścia bardziej rozbudowane uwzględniające większą liczbę poziomów, których przykłady podano w tabeli 2.

Analizując dane z tabeli 2, warto zauważyć, że rozumienie profilaktyki chorób zmieniało się, co w konsekwencji prowadziło do różnych sposobów działania. Obecnie posługiwanie się trzystopniowym podziałem profilaktyki nie jest powszechnie obowiązujące. Ponadto na uwagę zasługuje fakt, że zapobieganie chorobom w znaczeniu potocznym nie dotyczy leczenia, czyli profilaktyki trzeciorzędowej, którą wyróżniają profesjonaliści. Biorąc pod uwagę różnorodność profesjonalnych podejść do profilaktyki oraz popularność laickiej interpretacji pojęcia, warto jest zachować dużą ostrożność i precyzję w komunikacji dotyczącej zapobiegania chorobom.

W Polsce, zarówno w języku potocznym, jak w dokumentach formalnych i piśmiennictwie naukowym, powszechnie używa się terminu „profilaktyka zdrowotna”, co dosłownie oznacza zapobieganie zdrowotne, a więc w istocie niczego nie oznacza, toteż nie powinno się tak mówić czy pisać. Nierzadko używa się określenia „profilaktyka zdrowia”, co wskazywałoby na zapobieganie zdrowiu (!) i należy stanowczo się temu przeciwstawiać. W kontekście zapo-

19 WHO, Glossary of terms used in the „Health for All” series $n r$ 1-8, WHO, Geneva 1984, s. 17. 
Tabela 2. Przykłady podejść do profilaktyki chorób

\begin{tabular}{|l|c|l|}
\hline \multicolumn{1}{|c|}{$\begin{array}{c}\text { Kryterium } \\
\text { podziału }\end{array}$} & \multicolumn{1}{c|}{$\begin{array}{c}\text { Liczba poziomów/faz lub } \\
\text { rodzaj profilaktyki }\end{array}$} & \multicolumn{1}{c|}{ Autor, rok } \\
\hline \multirow{3}{*}{$\begin{array}{l}\text { Historia naturalna } \\
\text { choroby }\end{array}$} & 5,3 & $\begin{array}{l}\text { Hugh Leavell, E. Guerney Clark, } \\
1953,1958,1965\end{array}$ \\
\cline { 2 - 3 } & \multicolumn{1}{|c|}{ wczesna (primordial) } & Bogdan Kleczkowski, 1965 \\
\cline { 2 - 3 } $\begin{array}{l}\text { Populacja } \\
\text { docelowa, ryzyko }\end{array}$ & 2 (indywidualna wysokiego ryzyka, populacyjna) & Reoffrey Rose, 1985 \\
\hline $\begin{array}{l}\text { Konsekwencje } \\
\text { choroby }\end{array}$ & 3 (impairment, disability, handicap) & WHO, 1976 \\
\hline Cel, potrzeby & z prądem, pod prąd (downstream, upstream) & Irving Zola, John B. McKinlay 1979 \\
\cline { 2 - 3 } & 4 & Andrew Tannahill, 1985 \\
\hline Medykalizacja & czwartorzędowa (quaternary) & Marc Jamoulle, 1986 \\
\hline $\begin{array}{l}\text { Cel, populacja } \\
\text { docelowa }\end{array}$ & 7 & $\begin{array}{l}\text { Paul Froom, Jochanan Benbassat, } \\
2000\end{array}$ \\
\hline Stadium choroby & 5 & Ronald Hattis, 2009 \\
\hline
\end{tabular}

biegania rakowi piersi można spotkać się ze sformułowaniem „profilaktyka piersi” ${ }^{20}$, które oznacza zapobieganie piersiom i jest zupełnym nonsensem.

Powszechnie stosuje się termin „badania profilaktyczne”, co sugeruje jakoby same badania lekarsko-diagnostyczne miały moc zapobiegawczą. Takiemu określeniu (np. propagowanie mammografii jako badania profilaktycznego) sprzeciwiło się wielu ekspertów, ponieważ istnieją dowody, że dla znacznego odsetka kobiet taki przekaz oznacza (niesłusznie), że mammografia zapobiega zachorowaniu lub zmniejsza ryzyko zachorowania na raka piersi. Ponadto problemy znaczeniowe wynikają z równoczesnego używania terminów „profilaktyka” i „prewencja”, podczas gdy według słownika języka polskiego prewencja oznacza wyłącznie zapobieganie naruszaniu norm prawnych. Są to kolejne przykłady na dowód postawionej wcześniej tezy o konieczności opracowania leksykonu zdrowia publicznego, ustalenia wspólnego, precyzyjnego i poprawnego języka. Należy bowiem pamiętać, że język ma wpływ na poznanie, a więc myślenie, percepcję rzeczywistości i działanie ${ }^{21}$.

Według Macieja Dercza i Huberta Izdebskiego kwestie zapobiegania chorobom uregulowane w licznych aktach prawnych nie kładą dostatecznego akcentu na obligatoryjność prowadzenia działalności profilaktycznej, w szczególności

${ }^{20}$ Onkolmed Lecznica Onkologiczna s.c., Profilaktyka piersi szansa na życie bez raka, https://onkolmed.pl/profilaktyka-piersi-szansa-na-zycie-bez-raka [dostęp: 22 listopada 2018 r.]; Profilaktyka piersi, badania, kontrola i leczenie, http://www.profilaktykapiersi.pl/ [dostęp: 22 listopada 2018 r.].

${ }^{21}$ L. Broditsky, How Language Shapes Thought The languages we speak affect our perceptions of the world, „Scientific American” February 2011, s. 63-65, https://www.gwashingtonhs.org/ourpages/auto/2013/10/23/68598699/sci-am-2011.pdf [dostęp: 22 listopada 2018 r.]. 
w stosunku do dzieci i osób w podeszłym wieku, które to grupy mają w tym zakresie szczególne prawa wynikające z art. 68 ust. 3 Konstytucji RP². Autorzy ci wykazali również inne niedostatki uregulowań dotyczących profilaktyki. Wnioski takie wyciągnęli na podstawie analizy prawa ustrojowego, materialnego i formalnego przeprowadzonej przed uchwaleniem ustawy z 11 września $2015 \mathrm{r}$. o zdrowiu publicznym (Dz.U. poz. 1916, ze zm.), jednak ustawa ta nie poprawiła w istotnym stopniu sytuacji. Niewątpliwą zmianą jest zwiększenie roli Ministerstwa Zdrowia jako koordynatora działań profilaktycznych. Niewielką korektę ze względu na wymienione grupy docelowe wprowadził „Narodowy program zdrowia na lata 2016-2020"23.

\section{Promocja zdrowia}

Według Karty Ottawskiej24, czyli międzynarodowego porozumienia zawartego pod egidą WHO w 1986 r. w Ottawie, promocja zdrowia jest procesem, który umożliwia ludziom zwiększenie kontroli nad zdrowiem, panowania nad nim, oraz poprawę zdrowia ${ }^{25}$. Proces ten polega na działaniach w pięciu priorytetowych obszarach, takich jak: (1) tworzenie prozdrowotnej polityki publicznej, (2) tworzenie środowisk, które wspierają zdrowie, (3) wzmocnienie działań społeczności, upodmiotowienie ich, (4) kształtowanie umiejętności osobistych oraz (5) reorientacja świadczeń zdrowotnych, aby ich zakres nie ograniczał się do leczenia chorób.

Proklamowanie Karty było powiązane z doktrynalnym przejściem do epoki nowego zdrowia publicznego, ponieważ promocja zdrowia opiera się na społeczno-środowiskowym modelu zdrowia. Niestety, do dzisiaj w skali globalnej większość działań promocji zdrowia skierowana jest na poziom jednostki i wiąże się ze zmianą świadomości i zachowań. W Polsce jest to dominujący sposób prowadzenia promocji zdrowia. Pozytywne wyjątki stanowią projekty w szkołach promujące zdrowie, projekty promocji zdrowia w firmach oraz w szpitalach i placówkach medycznych, a także projekty sieci „Zdrowych Miast Polskich”.

${ }^{22}$ M. Dercz, H. Izdebski, Prawne aspekty organizacji i funkcjonowania systemu zdrowia publicznego w Polsce. (Analiza prawa ustrojowego, materialnego i formalnego), raport sporzadzony w ramach poddziałania 1.2: „Diagnoza obecnej organizacji i funkcjonowania systemu zdrowia publicznego w Polsce", realizowanego w ramach Programu PL 13: Ograniczenie społecznych nierówności w zdrowiu, wspótfinansowanego ze środków Norweskiego Mechanizmu Finansowego 2009-2014, Warszawa 2015, http://bazawiedzy.pzh.gov.pl/nierownosci-w-zdrowiu [dostęp: 29 września 2018 r.].

${ }^{23}$ Rozporządzenie Rady Ministrów z 4 sierpnia 2016 r. w sprawie Narodowego Programu Zdrowia na lata 2016-2020, Dz.U. poz. 1492.

${ }^{24}$ Ottawa Charter for health promotion, „Health Promotion International” 1986, t. 1, nr 4, s. iii-v.

${ }_{25}$ D. Nutbeam, Health promotion glossary, WHO, Geneva 1998, s. 1-2. 
Analizy historyczne pokazują, że od początku XX wieku w piśmiennictwie naukowym terminy „promocja zdrowia” i „promowanie zdrowia”, a także „duch promocji zdrowia” nie były rzadkością. Natomiast mniej więcej od połowy lat 40. do połowy lat 70. XX wieku promocja zdrowia zniknęła $\mathrm{z}$ dyskursu fachowego, co wynikało z dużej wówczas podejrzliwości wobec interwencjonizmu państwowego, silnych tendencji indywidualistycznych i akcentu na osobiste świadczenia zdrowotne. Spektakularny powrót wspólnotowego podejścia do zdrowia nastąpił w połowie lat 80 . XX wieku. Zanim jednak proklamowano Kartę Ottawską, w piśmiennictwie pojawiały się różne sugestie dotyczące promocji zdrowia lub promowania zdrowia, a także interpretacje działalności o tym charakterze. Również po ogłoszeniu Karty proponowano różne podejścia do promocji zdrowia, jednak WHO od lat konsekwentnie utrzymuje swoje pierwotne stanowisko z tego dokumentu. Trzeba też powiedzieć, że po 1986 r. rozwój promocji zdrowia w USA przebiegał nieco innymi szlakami niż w Kanadzie, Europie Zachodniej czy Australii, tj. z silniejszym akcentem na czynniki indywidualne i styl życia w przeciwieństwie do pozostałych rejonów, gdzie eksponowano warunki życia.

W Polsce podstawowa definicja promocji zdrowia pochodzi z art. 2 ust. 1 pkt 7 ustawy z 15 kwietnia 2011 r. o działalności leczniczej (Dz.U. nr 112, poz. 654, ze zm.), gdzie stwierdza się, że są to: działania umożliwiające poszczególnym osobom i społeczności zwiększenie kontroli nad czynnikami warunkujacymi stan zdrowia i przez to jego poprawe, promowanie zdrowego stylu życia oraz środowiskowych i indywidualnych czynników sprzyjających zdrowiu. Zgodnie z przywołaną ustawą działalność lecznicza może, obok podstawowej działalności polegającej na udzielaniu świadczeń zdrowotnych, polegać na promocji zdrowia (art. 3 ust. 2). Definicja z ustawy, podobnie jak wiele innych używanych w różnych krajowych opracowaniach, jest swobodną interpretacją definicji WHO.

Maciej Dercz i Hubert Izdebski stwierdzili, że: [z]agadnienia z zakresu promocji zdrowia należą do najbardziej ogólnikowo potraktowanych przez ustawodawcę. Zauważalny jest brak docenienia możliwości efektywnego prowadzenia przez władze publiczne promocji zdrowia i potraktowanie tego zagadnienia hasłowo, bez wskazania sposobów i metod prowadzenia skutecznych akcji promocyjnych ${ }^{26}$.

\section{Nakłady na zdrowie publiczne w systemie zdrowotnym}

Według WHO system zdrowotny (w Polsce najczęściej nazywany systemem ochrony zdrowia) to zbiór wszystkich publicznych i prywatnych organizacji i instytucji oraz zasobów formalnie nastawionych na poprawę, utrzymanie lub przywracanie zdrowia. System obejmuje świadczenia indywidualne oraz popula-

26 M. Dercz, H. Izdebski, Prawne aspekty organizacji i funkcjonowania systemu zdrowia publicznego, op. cit. 
cyjne, a także działania, które mają wywrzeć wpływ na polityki i działania innych sektorów w tym celu, aby uwzględniać społeczne, środowiskowe i ekonomiczne determinanty zdrowia ${ }^{27}$. W systemie tym wyodrębnia się współpracujące ze sobą działy zdrowia publicznego i opieki zdrowotnej, ale też opieki społecznej.

Metodologia tzw. rachunków zdrowia według Organizacji Współpracy Gospodarczej i Rozwoju (OECD) pozwala na zestawienie wydatków na ochronę zdrowia i dostarcza ważnych danych do porównań międzynarodowych. Zestawieniu podlegają wydatki publiczne i prywatne, przy czym nie uwzględnia się wydatków np. na polityczne działania systemu. Według OECD ${ }^{28}$ całkowite wydatki na zdrowie w Polsce w 2016 r. wynosiły 6,4\% PKB przy średniej dla członków OECD wynoszącej 9,0\%. W 2015 r. wynosiły 6,3\% PKB, przy średniej $8,9 \%$. Publiczne wydatki w obu latach wynosiły 4,4\% PKB w Polsce, przy średniej OECD 6,5\%. Tak więc zarówno całkowite (publiczne i prywatne), jak też wyłącznie publiczne (budżetowe i z ubezpieczeń zdrowotnych) wydatki na ochronę zdrowia były w Polsce znacznie niższe niż średnia w państwach OECD.

W 2016 r. publiczne wydatki na profilaktykę (w tym: informację, edukację i poradnictwo, program szczepień ochronnych, programy wczesnego wykrywania chorób, programy monitorowania stanu zdrowia, nadzór epidemiologiczny i kontrolę chorób, przygotowanie do sytuacji kryzysowych i reagowanie) wynosiły 36,9 dolarów US na jednego mieszkańca Polski przy średniej dla OECD wynoszącej 89,5 dolarów US (wykres 1).

W świetle tych danych warto krótko omówić sytuację w Kanadzie, która wydaje najwięcej na świecie na świadczenia profilaktyczne w przeliczeniu na jednego mieszkańca ${ }^{29}$ i sytuacja taka utrzymuje się od lat ${ }^{30}$. A jakie są skutki tej - wydawałoby się - doskonałej sytuacji?

Kraj ten jest dziesiątą gospodarką świata, toteż dysponuje większą pulą pieniędzy na wydatki związane ze zdrowiem. Dla porównania z Polską można powiedzieć, że, biorąc pod uwagę ostatnie dostępne dane o kolejnych wskaźnikach sytuacji (nie zawsze dotyczące tego samego roku kalendarzowego), Kanada ma około półtora raza większy PKB od Polski ${ }^{31}$ i większy odsetek tej kwoty przeznacza na cele zdrowotne ${ }^{32}$. Populacja Kanady liczy ok. 36,7 mln osób ${ }^{33}$, a więc jest wielkością

${ }^{27}$ The Tallinn Charter: Health Systems for Health and Wealth, WHO Regional Office for Europe, Copenhagen 2008.

${ }_{28}$ OECD. Stat. Health expenditure and financing, http://stats.oecd.org/index. aspx?DataSetCode=HEALTH_STAT [dostęp: 23 września 2018 r.].

29 Dane OECD: 291,8 dolarów US w 2016 r.

30 Dane OECD: 244,8 dolarów US w $2010 \mathrm{r}$.

31 Dane OECD: PKB Kanady wynosił 1512,97 mld dolarów US według parytetu siły nabywczej w 2015 r., a Polski - 909,27 mld dolarów US.

32 Dane OECD: w Kanadzie 10,5\% PKB w 2016 r., a w Polsce 6,4\% PKB.

33 Dane Statistics Canada: 36708083 osób w 2017 r.; https://www150.statcan.gc.ca/n1/ pub/12-581-x/2018000/pop-eng.htm [dostęp: 22 listopada 2018 r.]. 


\section{Wykres 1. Publiczne wydatki na świadczenia profilaktyczne na osobę wg parytetu siły nabywczej w krajach OECD w 2016 r. \\ (w dolarach US)}

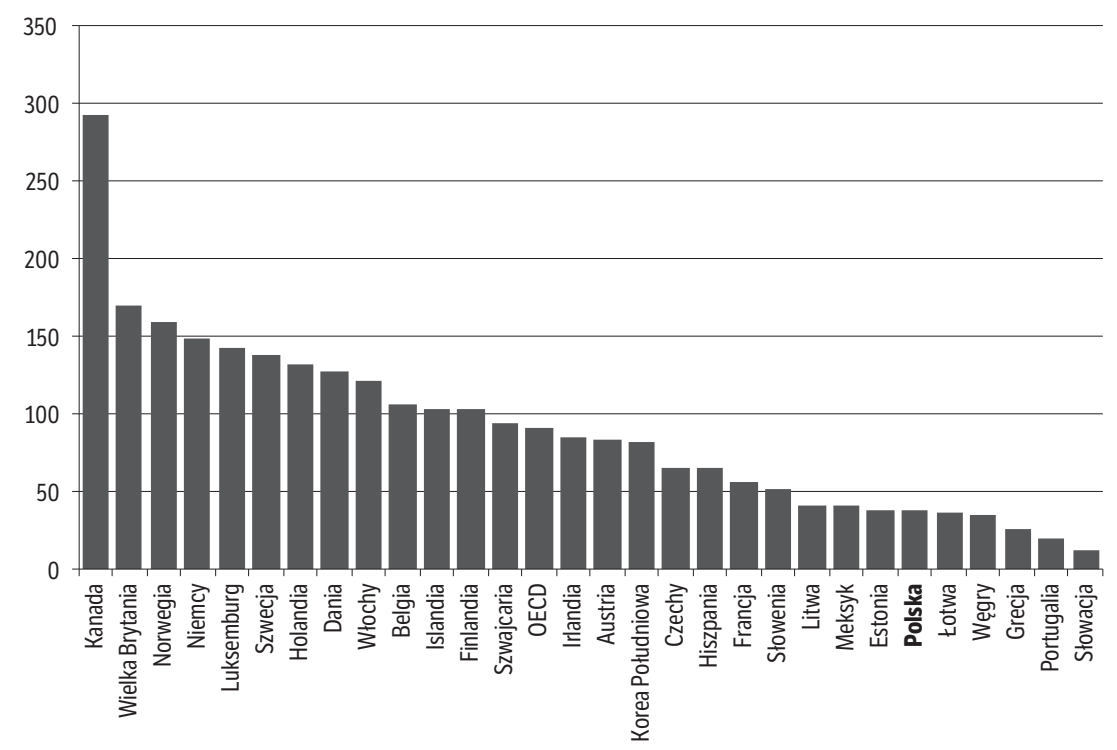

Źródło: na podstawie danych z OECD, Stat. Health expenditure and financing, http://stats.oecd.org/index. aspx?DataSetCode=HEALTH_STAT [dostęp: 23 września 2018 r.].

zbliżoną do polskiej, która według GUS w tym samym roku liczyła ok. 38,4 mln osób $^{34}$. Ponadto w Kanadzie istnieje powszechne ubezpieczenie zdrowotne.

Oceniając tę sytuację pod kątem wskaźnika, jakim jest oczekiwane trwanie życia w chwili urodzin dla obu płci, to trzeba stwierdzić, że Kanadyjczycy żyją o 4,3 roku dłużej niż Polacy ${ }^{35}$, a więc sytuacja jest tam relatywnie lepsza. Pomimo tego wielu kanadyjskich ekspertów z dziedziny zdrowia publicznego negatywnie ocenia sytuację i twierdzi, że obecny sposób dystrybucji nie ma istotnego wpływu ani na umieralność, ani na ograniczanie społecznych nierówności w zdrowiu. Według ich ustaleń i opinii kwoty przeznaczone na zdrowie są niewłaściwie dystrybuowane - za mało pieniędzy przeznacza się na promocję zdrowia, a także na działania społeczne (takie jak np. niwelowanie bezrobocia czy poprawa edukacji ${ }^{36}$. Stawia się wnioski o redystrybucję środków w taki

${ }^{34}$ Dane GUS: 38433558 osób w dniu 31 grudnia 2017 r., „Rocznik Demograficzny GUS" 2018, s. 34 .

${ }^{35}$ Dane OECD: oczekiwany czas życia w Kanadzie wynosił 81,9 roku w 2015 r., a w Polsce 77,6 roku.

${ }^{36}$ D. Raphael, Health inequalities in Canada: current discourses and implications for public health action, „Critical Public Health” 2000, t. 10, nr 2, s. 193-216; T. Bryant, D. Raphael, T. Schrecker, R. Labonté, Canada: A land of missed opportunity for addressing the social 


\section{Wykres 2. Publiczne wydatki na świadczenia profilaktyczne na osobę wg parytetu siły nabywczej w Polsce w latach 2002-2016 r. \\ (w dolarach US)}

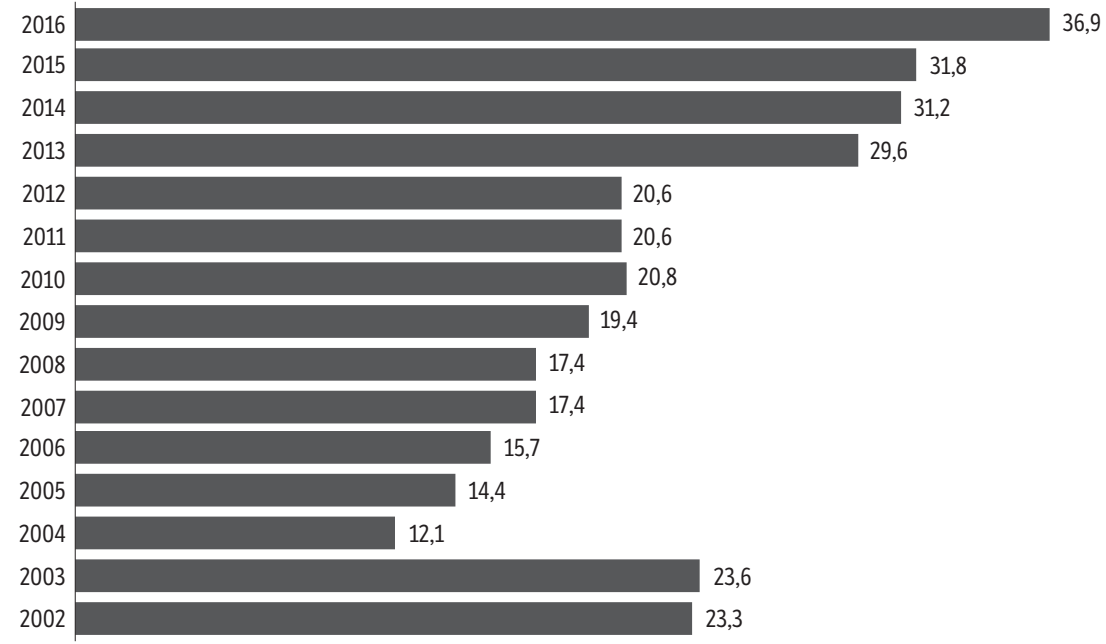

Źródło: jak pod wykresem 1.

sposób, aby część kwot przeznaczonych na zdrowie kierować na cele społeczne ${ }^{37}$. Miałoby to polegać nie tyle na zasiłkach, świadczeniach w naturze czy zwrocie podatków, ale przede wszystkim na różnorodnych formach wsparcia dla społeczności, takich jak np. asystowanie rodzinom, osobom starym, chorym, wykluczonym. Wnioski, jakie płyną z tego dla Polski, są więc takie, że nawet duża alokacja środków na cele stricte zdrowotne sama w sobie nie jest wystarczająca dla istotnej poprawy zdrowotności populacji. Niezbędne są inwestycje w warunki społeczne i promocję zdrowia w znaczeniu Karty Ottawskiej.

Trzeba jednak podkreślić, że wydatki na świadczenia profilaktyczne na jednego mieszkańca w Polsce stopniowo rosną. W latach 2002-2016 poziom tych wydatków podlegał istotnym wahaniom, ale od 2013 r. obserwuje się ich stopniowy wzrost (wykres 2).

Powszechnie podkreśla się, że nakłady na zdrowie nie są kosztem a inwestycją. Według danych WHO działania zdrowia publicznego ukierunkowane

determinants of health, „Health Policy” 2010, t. 101, nr 1, s. 44-58, doi:10.1016/j.healthpol.2010.08.022, https://www.researchgate.net/publication/47298612_Canada_A_land_of_ missed_opportunity_for_addressing_the_social_determinants_of_health [dostęp: 22 listopada 2018 r.].

${ }^{37}$ D.J. Dutton, P.G. Forest, R.D. Kneebone, J.D. Zwicker, Effect of provincial spending on social services and health care on health outcomes in Canada: an observational longitudinal study, „CMAJ” 2018, t. 190, nr 3, s. E66-E71, doi:10.1503/cmaj.170132 [dostęp: 22 listopada 2018 r.]. 
na czynniki środowiskowe (np. zielona przestrzeń miejska, aktywny transport, izolacja termiczna budynków), psychospołeczne i behawioralne (np. zapobieganie przemocy, ograniczanie dostępności alkoholu, zwiększanie aktywności fizycznej i poprawa diety), szczepienia ochronne, niektóre masowe programy badań przesiewowych (skriningowych) ${ }^{38}$ przynoszą zwrot kosztów w okresie do pięciu lat od wdrożenia. Koszty wielu innych interwencji zwracają się po pięciu latach, a niektóre przynoszą oszczędności ${ }^{39}$. Coraz częściej podnoszona jest więc konieczność realokacji środków finansowych z medycyny naprawczej na programy zdrowia publicznego i społeczne.

\section{Praktyka zdrowia publicznego}

Świadczenia zdrowia publicznego w obszarze profilaktyki i promocji zdrowia najczęściej przebiegają pod postacią interwencji, programów i projektów, przy czym terminy te nie mają w piśmiennictwie naukowym powszechnie uzgodnionej definicji. I tak np. interwencja może oznaczać większą całość (np. interwencję skriningową realizowaną za pomocą programu cytologicznego lub mammograficznego), gdzie jest synonimem szerszego planu działania. Może też oznaczać działanie w obrębie określonego programu (np. interwencja edukacyjna w programie skriningowym) i jest wtedy odpowiednikiem metody działania. Tę drugą wykładnię stosuje Agencja Oceny Technologii Medycznych i Taryfikacji (AOTMiT) w schemacie programu zdrowotnego lub programu polityki zdrowotnej. Aby uniknąć rozważań definicyjnych, w dalszej części tego opracowania działania zdrowia publicznego będą nazywane po prostu programami zdrowotnymi lub programami zdrowia publicznego, czyli tak jak to jest najczęściej stosowane w piśmiennictwie.

\section{Program zdrowotny}

Program jest zespołem działań, które realizuje się w odpowiedzi na potrzeby określonej grupy lub polityki. Jego celem jest osiągnięcie korzystnej zmiany i uzyskanie takich rezultatów, które można zidentyfikować. Beneficjentem programu powinny być grupy osób, wszyscy członkowie danej społeczności albo ogół ludności. Program powinien opierać się na teoriach naukowych i dowo-

38 Masowe badania przesiewowe (skriningowe, inaczej skrining) polegają na zastosowaniu procedur i technologii, dzięki którym można podczas badania odróżnić osoby, które mają objawy przedmiotowe i podmiotowe chorób, od osób, które takich jednoznacznych objawów nie mają, zob. Centers for Disease Control and Prevention, National Public Health Performance Standards Glossary, Version 3.0, http://www.astho.org/Accreditation/National-Public-Health-Performance-Standards-Version-3_0-Glossary/ [dostęp: 22 listopada 2018 r.].

39 The case for investing in public health. The strengthening public health services and capacity, WHO Regional Office for Europe, 2014. 
dach naukowych, a więc mieć twarde uzasadnienie naukowe. Inną cechą charakterystyczną programu jest wielodyscyplinarność i wielosektorowość.

Programy zdrowia publicznego mogą mieć charakter odgórny (instytucjonalny), kiedy profesjonaliści sami wybierają tematykę (problem zdrowotny) oraz metody rozwiązania problemu i sami opracowują plan działania, lub oddolny, kiedy profesjonaliści wspierają społeczność, aby to ona określiła ważne dla niej życiowe problemy, a także podjęła decyzje co do sposobów ich rozwiązania. Każde z podejść ma dobre i złe strony i może z różnych powodów okazać się dysfunkcjonalne. W kwestii nierówności w zdrowiu i działań w obszarze społecznych uwarunkowań zdrowia uzasadnione jest jednoczesne korzystanie z obu podejść. Przeważająca większość programów w Polsce ma charakter odgórny. Są to w szczególności programy realizowane przez jednostki samorządu terytorialnego.

Trzeba też zaznaczyć, że wszystkie programy zdrowia publicznego są silnie zależne od kontekstu, czyli warunków demograficznych, społecznych, instytucjonalnych, organizacyjnych czy politycznych, w jakich mają być prowadzone, a więc są bardzo różnorodne i trudne do porównań. Oznacza to również, że dla praktyki zdrowia publicznego duże znaczenie mają informacje o dobrych praktykach, czyli programach, które wykazały się skutecznością w różnych kontekstach. Niestety, o czym bardziej szczegółowo będzie mowa dalej, nie mamy w Polsce własnej bazy dobrych praktyk.

\section{Planowanie programów zdrowotnych}

Programy planuje się za pomocą specjalnych schematów (tzw. modeli). Znanych jest kilkanaście schematów odpowiednich do potrzeb zdrowia publicznego, a każdy ma swoje mocne i słabe strony. Rozumienie zdrowia publicznego, oparte na związkach przyczynowo-skutkowych, dyktuje, aby pierwszym etapem działania była analiza sytuacji, określenie potrzeb i zdefiniowanie problemu do rozwiązania. Kolejnym krokiem jest identyfikacja różnorodnych przyczyn problemu wraz z określeniem czynników ochronnych. Następnie ustala się cele i zadania, strategie i metody, planuje monitorowanie i ewaluację. Na etapie definiowania problemu oraz przy wyborze celów, zadań, strategii i metod korzysta się z zasad zdrowia publicznego opartego na dowodach i baz dobrych praktyk. Jeśli planuje się zmianę zachowań, to kardynalne znaczenie ma wykorzystanie teorii na temat genezy problemów lub zmiany zachowań. Analiza Rachel Davies i współpracowników wykazała, że obecnie znanych jest ok. 80 takich teorii, z czego zaledwie kilka jest w stałym użyciu ${ }^{40}$. Doświadczenie uczy, że większość programów w Polsce nie opiera się na żadnej teorii. Tak przygotowany program poddaje się pilotażowi, aby następnie wdrożyć go na zaplanowaną skalę. W trak-

40 R. Davis i in., Theories of behaviour and behaviour change across the social and behavioral sciences: a scoping review, „Health Psychology Review” 2015, t. 9, nr 3, s. 323-344, https:// doi.10.1080/17437199.2014.941722 [dostęp: 23 września 2018 r.]. 
cie realizacji dokonuje się monitorowania, a na zakończenie poddaje ocenie wartościującej - ewaluacji, której wyniki udostępnia wszystkim zainteresowanym stronom. Jeśli efekty programu są korzystne, to można próbować wdrażać go w innych kontekstach, a jeśli i to się powiedzie, to program pretenduje do miana dobrej praktyki.

Do planowania, ewaluacji oraz prezentacji planu programu różnym interesariuszom bardzo przydatny jest tzw. model logiczny, w którym umieszcza się kolejno: nakłady, działania, produkty, oraz efekty krótko-, średnio- oraz długoterminowe (alternatywnie rezultaty i oddziaływanie). Model logiczny jest szeroko wykorzystywany w praktyce zdrowia publicznego na świecie, ale w ogóle nie jest stosowany w Polsce, co wynika z faktu, że nie ma takiego obowiązku zapisanego prawnie ani też powszechnej umiejętności sporządzenia takich modeli. Piśmiennictwo anglojęzyczne dostarcza bardzo licznych publikacji na temat zasad i warsztatu planowania programów, ale polskojęzyczne jest w tym zakresie bardzo ubogie i niewystarczające. Odbija się to na jakości planowanych działań, czego dowodem jest niska jakość projektów programów zdrowotnych lub programów polityki zdrowotnej nadsyłanych do AOTMiT celem ich zaopiniowania ${ }^{41}$.

\section{Dobre praktyki}

Zdrowie publiczne oparte na dowodach zaczęto definiować od końca lat 90. XX wieku, a więc z pewnym opóźnieniem w stosunku do początku ery medycyny opartej na dowodach, którą w 1992 r. ogłosiła grupa robocza pn. Evidence-Based Medicine Working Group ${ }^{42}$. Zgodnie z fundamentalną definicją Rossa Brownsona i współpracowników podejście zdrowia publicznego opartego na dowodach polega na wykorzystaniu zasad rozumowania naukowego, systematycznego wykorzystywania danych i systemów informacji oraz odpowiedniego użycia modeli planowania do tworzenia, wdrożenia i ewaluacji skutecznych programów i polityk ${ }^{43}$. Pamiętając, że R. Brownson udoskonalał i rozwijał tę pierwszą definicję, można za Nealem Kohatsu przyjąć, że podejście to polega na łączeniu nauki z preferencjami społeczności ${ }^{44}$. W praktyce polega to na tym, aby w programach uwzględnić nie tylko teorie i dowody naukowe, ale również

41 R. Rdzany, Krytyczna analiza lokalnych programów z zakresu profilaktyki chorób przewlekłych oraz promocji zdrowia, przewidzianych do realizacji na szczeblu powiatów i gmin, zgłoszonych do Agencji Oceny Technologii Medycznych, Warszawa, maj 2015 r., http://bazawiedzy.pzh.gov.pl/nierownosci-w-zdrowiu [dostęp: 22 września 2018 r.].

42 Evidence-Based Medicine Working Group, Evidence-based medicine. A new approach to teaching the practice of medicine, „JAMA” 1992, t. 268, nr 17, s. 2420-2425.

43 R.C. Brownson, J.G. Gurney, G.H. Land, Evidence-based decision making in public health, „J Public Health Management Practice” 1999, t. 5, nr 5, s. 86-97.

${ }^{4}$ N.D. Kohatsu, J.G. Robinson, J.C. Torner, Evidence-based public health: an evolving concept, „American Journal of Preventive Medicine” 2004, t. 27, nr 5, s. 417-421, doi:10.1016/j. amepre.2004.07.019 [dostęp: 22 września 2018 r.]. 
potrzeby społeczności, jej zasoby oraz preferencje, a także kontekstowe uwarunkowania życia ludzi i realizacji programu.

Naukowe podstawy programu mają wynikać z różnych teorii dotyczących np. postrzegania zdrowia i choroby, zmiany zachowań, organizacji społeczności czy komunikacji oraz dowodów naukowych na racjonalność programu. Biorąc pod uwagę ten drugi czynnik, tj. racjonalność, w trakcie planowania programu wybiera się takie rozwiązania (strategie i metody), które miały realny wpływ na poprawę sytuacji i są na to mocne dowody z badań empirycznych, ewaluacyjnych lub podobnych programów. Informacji na takie tematy dostarczają tzw. bazy dobrych praktyk, spośród których można wymienić np. National Institute for Health and Care Excellance, Community Preventive Services Task Force, US Preventive Services Task Force, Canadian Task Force on Preventive Health Care.

Dla wyjaśnienia trzeba powiedzieć, że realny wpływ dowolnego programu można oceniać pod kątem różnych kryteriów, np.: skuteczności, dotarcia do grupy docelowej, wykonalności, trwałości, możliwości transferu do innych środowisk. Uzyskane dowody na spełnienie tych kryteriów mogą być słabe, średnie, mocne i pewne. Działania, których wpływ pod kątem wymienionych kryteriów ocenia się jako duży, a dowody na to są pewne (na podstawie przeglądów systematycznych lub metaanaliz), nazywa się najlepszymi praktykami. Pozostałe konfiguracje wpływu i dowodów wskazują praktyki wschodzące, obiecujące i wiodące. Istnieją też inne, nieco mniej rygorystyczne, zasady wyłaniania dobrych praktyk.

Trzeba pamiętać, że każdy transfer programu jest bardzo skomplikowanym procesem. Co więcej, nie wszystkie skuteczne programy można przenieść z krajów rozwiniętych do odmiennych kontekstów społecznych, technologicznych czy ekonomicznych. Wiadomo bowiem, że w populacjach biedniejszych wykorzystanie najbardziej efektywnych interwencji zdrowotnych jest o połowę mniejsze niż w krajach bogatszych, a efektywność tych wdrożonych jest niewielka ${ }^{45}$. $\mathrm{Z}$ tego powodu wierne kopiowanie innych programów, nawet zaliczonych do dobrych praktyk, nie musi się zakończyć sukcesem.

Jedyną w Polsce bazą dobrych praktyk jest istniejący od 2010 r. system rekomendacji programów z obszarów promocji zdrowia psychicznego, profilaktyki uzależnień oraz profilaktyki innych zachowań problemowych dzieci i młodzieży ${ }^{46}$. Jest on wynikiem współpracy Krajowego Biura ds. Przeciwdziałania Narkomanii, Państwowej Agencji Rozwiązywania Problemów Alkoholowych, Ośrodka Rozwoju Edukacji oraz Instytutu Psychiatrii i Neurologii. System ten za pomocą określonych kryteriów kwalifikuje nadesłane programy do trzech poziomów: jako program obiecujący, dobrą praktykę lub program modelowy. Obecnie (stan na 23 września 2018 r.) w systemie figuruje 28 programów.

${ }^{45}$ P. Tugwell, V. Robinson, J. Grimshaw, N. Santesso, Systematic review and knowledge translation, „Bulletin of World Health Organization” 2006, t. 84, nr 8, s. 643-651.

46 Http://www.programyrekomendowane.pl/ [dostęp: 23 września 2018 r.]. 
W Polsce nie mamy innej bazy dobrych praktyk opartej na wynikach krajowych badań ewaluacyjnych, ponieważ tylko znikoma część programów realizowanych w kraju jest w ogóle poddawana ewaluacji ze względu na uzyskiwane efekty (ewaluacja efektu). Do nielicznych i chlubnych wyjątków należy np. samorządowy program szczepień przeciwko pneumokokom w Kielcach, gdzie kontrolowano rzeczywiste efekty zdrowotne ${ }^{47}$. Powstanie bazy dobrych praktyk utrudnia także brak spójnego systemu sprawozdawczości z realizowanych programów, takiego który byłby użyteczny dla różnych podmiotów i realizatorów programów. Otóż z mocy ustawy o zdrowiu publicznym w sprawozdaniu ze zrealizowanych lub podjętych zadań z zakresu zdrowia publicznego ${ }^{48}$ wśród wymaganych informacji uwzględnia się wyłącznie te, które dotyczą podmiotu realizującego zadanie, terenu realizacji zadania i charakterystyki populacji, a także niektórych nakładów (koszt, czas, realizator) oraz niektórych produktów (liczba uczestników i działań). Informacje te mogą służyć jedynie do ewaluacji procesu i nie mówią niczego o efektach, a więc realnym wpływie danego programu. Jednocześnie z mocy ustawy z 27 sierpnia 2004 r. o świadczeniach opieki zdrowotnej finansowanych ze środków publicznych (Dz.U. nr 210, poz. 2135, ze zm.) w raporcie końcowym z realizacji programu polityki zdrowotnej ${ }^{49}$ należy podać: przewidziany czas realizacji, opis sposobu osiągnięcia celów programu, charakterystykę interwencji, wyniki monitorowania i ewaluacji, koszty realizacji z podziałem na źródło finansowania i charakter wydatków (bieżące, majątkowe), koszty jednostkowe oraz problemy, jakie wystąpiły w trakcie realizacji wraz z opisem działań modyfikujących. W komentarzu podano między innymi, że w wynikach monitorowania i ewaluacji: należy ustosunkować się do efektów zdrowotnych uzyskanych i utrzymujących siępo zakończeniu programu polityki zdrowotnej, m.in. na podstawie wcześniej określonych mierników efektywności odpowiadajacych celom programu polityki zdrowotnej. Owo „ustosunkowanie się” ma mieć charakter opisowy, co utrudni jakąkolwiek analizę porównawczą efektów różnych programów. Ponadto wymienione wyżej sprawozdania i raporty mają innych adresatów, bowiem sprawozdania składane są bezpośrednio do ministra właściwego do spraw zdrowia lub pośrednio do niego za pośrednictwem wojewody, podczas gdy raporty są kierowane do AOTMiT.

Podsumowując tę część rozważań, można krótko powiedzieć, że praktyczna realizacja świadczeń zdrowia publicznego w Polsce napotyka liczne przeszkody

47 E. Bernatowska i in., Szczepienia ochronne przeciwko Streptococcus pneumoniae u dzieci. Raport Grupy na rzecz Programu Szczepień Ochronnych w Polsce, Stowarzyszenie Parasol dla Życia, Warszawa, marzec 2016 r.

${ }^{48}$ Rozporządzenie Ministra Zdrowia z 21 grudnia 2016 r. w sprawie rocznej informacji o zrealizowanych lub podjętych zadaniach z zakresu zdrowia publicznego, Dz.U. poz. 2216.

49 Rozporządzenie Ministra Zdrowia z 22 grudnia 2017 r. w sprawie wzoru programu polityki zdrowotnej, wzoru raportu końcowego z realizacji programu polityki zdrowotnej oraz sposobu sporządzenia projektu programu polityki zdrowotnej i raportu końcowego z realizacji programu polityki zdrowotnej, Dz.U. poz. 2476. 
wynikające zarówno z braku dobrych, opartych na teoriach i dowodach wzorców postępowania, jak też niezadowalającej organizacji i koordynacji tych prac, wreszcie niewłaściwego, bo bardziej formalnego niż merytorycznego, nadzoru nad działaniami.

\section{Rekomendacje dotyczące poprawy funkcjonowania zdrowia publicznego w Polsce}

Jak wspomniano wcześniej, szczegółowa analiza realizacji podstawowych funkcji zdrowia publicznego przeprowadzona w Polsce w 2015 r. doprowadziła do stworzenia bardzo licznych i drobiazgowych zaleceń. Poniżej zostaną w skróconej formie przedstawione najważniejsze $\mathrm{z}$ nich ${ }^{50}$ ( $\mathrm{z}$ wyłączeniem rekomendacji odnośnie do EPHO 9, tj. komunikacji, rzecznictwa zdrowotnego i mobilizacji społecznej na rzecz zdrowia, która nie była poddana ocenie). W następnych latach dokonano pewnych korekt w funkcjonowaniu zdrowia publicznego, niemniej większości zaleceń nie zrealizowano, a te podjęte nie zostały ocenione ze względu na uzyskane efekty i korzyści.

\section{Zalecenia do funkcji „Nadzór nad zdrowiem i dobrostanem” (EPHO 1)}

- Stworzenie systemu i narzędzi informacyjnych niezbędnych do zarządzania systemem zdrowia, w tym rejestrów medycznych.

- Poprawa mechanizmów przekazywania danych w badaniach statystycznych statystyki publicznej oraz w innych systemach gromadzenia danych i informacji.

- Wypracowanie i wdrożenie jednolitych zasad określania przyczyn zgonów dla celów statystyki publicznej.

- Pełniejsze monitorowanie działalności podstawowej opieki zdrowotnej.

- Pełniejsze monitorowanie sytuacji w zakresie chorób niezakaźnych, zdrowia psychicznego populacji i społecznych nierówności w zdrowiu.

\section{Zalecenia do funkcji „Monitorowanie zagrożeń dla zdrowia i sytuacji kryzysowych”} (EPHO 2)

- Stworzenie jednego spójnego systemu zarządzania kryzysowego w kraju.

- Włączenie resortu zdrowia do zadań z zakresu oceny jakości środowiska.

${ }^{50}$ D. Cianciara i in., Diagnoza istniejacej organizacji i funkcjonowania systemu zdrowia publicznego w Polsce - rzeczywisty sposób działania systemu, t. I, Podsumowanie, Narodowy Instytut Zdrowia Publicznego - Państwowy Zakład Higieny, Warszawa 2017, http://bazawiedzy. pzh.gov.pl/nierownosci-w-zdrowiu [dostęp: 22 listopada 2018 r.]; idem, Diagnoza istniejącej organizacji i funkcjonowania systemu zdrowia publicznego w Polsce - rzeczywisty sposób działania systemu, t. II, Narodowy Instytut Zdrowia Publicznego - Państwowy Zakład Higieny, Warszawa 2017, http://bazawiedzy.pzh.gov.pl/nierownosci-w-zdrowiu [dostęp: 22 listopada 2018 r.] 
- Uregulowanie zakresu działań poszczególnych resortów w odniesieniu do monitoringu chemicznych zagrożeń dla zdrowia.

- Poprawa koordynacji i nadzoru nad jakością wody przeznaczonej do spożycia i wody w kąpieliskach oraz ustalenie zasad monitorowania zbiorowego zaopatrzenia w wodę przeznaczoną do spożycia.

Zalecenia do funkcji „Ochrona zdrowia, w tym tzw. zdrowie środowiskowe, pracujących, bezpieczeństwo żywności" (EPHO 3)

- Prowadzenie działań informacyjnych i edukacyjnych, dotyczących środowiskowych zagrożeń dla zdrowia, bezpieczeństwa żywności, bezpieczeństwa i higieny pracy, bezpieczeństwa ruchu drogowego oraz bezpieczeństwa produktów, adresowanych do decydentów i społeczeństwa.

- Uregulowanie zakresu zadań i odpowiedzialności poszczególnych resortów i podmiotów w odniesieniu do środowiskowych zagrożeń dla zdrowia.

- Opracowanie i wdrożenie regulacji prawnych odnośnie do bezpieczeństwa środowiska zamieszkania (mieszkalnictwa).

- Opracowanie i wdrożenie regulacji prawnych odnośnie do bezpieczeństwa środowiskowego, w tym dotyczących obowiązku oceny ryzyka dla zdrowia w wyniku zanieczyszczenia środowiska, wdrażania działań ograniczających to ryzyko i systemu egzekwowania kar.

- Utworzenie ogólnodostępnej bazy danych o stanie środowiska, zagrożeniach, ryzyku i profilaktyce zagrożeń środowiskowych.

\section{Zalecenia do funkcji „Promocja zdrowia, w tym działania dotyczące społecznych} uwarunkowań zdrowia oraz nierówności w zdrowiu" (EPHO 4)

- Wyodrębnienie podmiotu o przywódczej roli w promocji zdrowia, kompetentnego w budowaniu potencjału i współpracy międzysektorowej.

- Upowszechnienie partnerstwa publiczno-prywatnego.

- Rewizja polityki dotyczącej sprzedaży alkoholu.

- Opracowanie i wdrożenie lub zrewidowanie istniejących krajowych polityk lub programów zdrowotnych dotyczących: nadwagi i otyłości, sportu, rekreacji i aktywności fizycznej, zdrowia seksualnego młodzieży, ochrony kobiet przed przemocą, promocji bezpieczeństwa i zapobiegania urazom.

Zalecenia do funkcji „Zapobieganie chorobom, w tym wczesne ich wykrywanie” (EPHO 5)

- Podejmowanie inicjatyw i poszukiwanie opartych na dowodach naukowych sposobów przeciwdziałania problemowi uchylania się rodziców i opiekunów dzieci przed obowiązkiem ich szczepienia.

- Weryfikacja przebiegu realizowanych aktualnie badań przesiewowych.

- Wprowadzenie obowiązku informowania przez lekarza kobiet do 10 tygodnia ciąży o możliwości wykonania badań w kierunku wad uwarunko- 
wanych genetycznie i odnotowania w karcie pacjentki faktu przekazania takiej informacji.

- Opracowanie i wdrożenie polityk lub programów ukierunkowanych na poprawę sytuacji zdrowotnej tzw. grup podatnych na utratę zdrowia (np. osoby niepełnosprawne, migranci, bezdomni).

- Rozszerzenie zakresu praw pacjenta o kwestię uśmierzania bólu.

Zalecenia do funkcji „Zapewnienie zarządzania (gospodarowania) zdrowiem” (EPHO 6)

- Wyznaczenie długoterminowych celów działania zdrowia publicznego.

- Opracowanie i wdrożenie mechanizmów planowania, monitorowania i ewaluacji polityk z zakresu zdrowia publicznego, w tym wdrożenie metody oceny wpływu (oddziaływania) na zdrowie.

- Poprawa współpracy międzysektorowej w zdrowiu publicznym i zwiększenie rzeczywistego udziału interesariuszy.

- Wzmocnienie zarządzania zdrowiem, w tym promowanie tzw. podejścia cały rząd i całe społeczeństwo dla zdrowia.

Zalecenia do funkcji „Zapewnienie kompetentnej kadry zdrowia publicznego" (EPHO 7)

- Ustalenie definicji pracownika zdrowia publicznego, jego kompetencji, oszacowanie kadr zdrowia publicznego, opracowanie polityki rozwoju kadr zdrowia publicznego i zarządzania zasobami ludzkimi.

- Stworzenie systemu oceny, akredytacji i certyfikacji podmiotów i pracowników zdrowia publicznego.

- Poprawa jakości kształcenia przed-i podyplomowego w dziedzinie zdrowia publicznego, szersze włączenie problematyki zdrowia publicznego do kształcenia przeddyplomowego i podyplomowego lekarzy.

\section{Zalecanie do funkcji „Zapewnienie struktury organizacyjnej i finansowania”}

(EPHO 8)

- Reorientacja systemu ochrony zdrowia w kierunku profilaktyki, poprawa jakości świadczeń leczniczych poprzez integrację, ciągłość opieki, wspieranie samoopieki, lokalizację świadczeń jak najbliżej pacjenta.

- Zwiększenie finansowania zdrowia publicznego.

- Szersze niż biomedyczne definiowanie zadań zdrowia publicznego.

- Rozwój potencjału zdrowia publicznego, rozwój współpracy międzysektorowej, zwiększanie kompetencji pracowników i wszystkich interesariuszy, stworzenie odpowiedniej infrastruktury, w tym sieci laboratoriów zdrowia publicznego.

- Wykorzystanie wachlarza metod zdrowia publicznego do poprawy środowiska przyrodniczego, antropologicznego i społecznego, położenie silnego akcentu na społeczne uwarunkowania zdrowia. 
- Stworzenie bazy danych, informacji, wzorców postępowania, analiz przypadków itp. materiałów pomocniczych dla realizatorów zadań.

- Systematyczne analizy i oceny funkcjonowania systemu zdrowia publicznego.

Zalecenia do funkcji „Rozwój badań w dziedzinie zdrowia publicznego dla potrzeb polityki oraz praktyki" (EPHO 10)

- Ustalenie krajowych priorytetów badawczych w dziedzinie zdrowia publicznego i stworzenie skutecznego mechanizmu finansowania badań w tej dziedzinie.

- Wdrożenie mechanizmów translacji wiedzy i brokerstwa wiedzy.

- Ułatwienie badaczom dostępu do rejestrów publicznych i medycznych.

- Dążenie do współpracy badaczy z praktykami zdrowia publicznego.

\section{Podsumowanie}

System zdrowia publicznego, czyli składowa systemu zdrowotnego, to zbiór wszystkich podmiotów publicznych i prywatnych oraz wolontariuszy, których działania przyczyniają się do realizacji zadań wynikających z funkcji zdrowia publicznego. Wiodącym podmiotem są agencje rządowe, które powinny być wspierane przez podmioty lecznicze, placówki oświaty i wychowania, organizacje sportowe i rekreacyjne, organizacje związane z ochroną środowiska czy organizacje charytatywne.

Jak wynika z wymienionych wyżej zaleceń, system zdrowia publicznego w Polsce stoi przed licznymi problemami i wyzwaniami. Które z tych problemów są najważniejsze? Które wymagają szczególnej uwagi? Należy przypuszczać, że odpowiedzi na te pytania byłyby różne w zależności od tego, kto i z jakiej perspektywy udziela tej odpowiedzi. Z własnej perspektywy chciałabym wskazać trzy kwestie.

Po pierwsze, zdrowie publiczne jest działalnością wielosektorową i międzysektorową oraz wielodyscyplinarną. I jak każda działalność zespołowa wymaga współpracy, w tym partnerstwa i dobrej komunikacji. Od dobrej komunikacji zależy też rozwój potencjału zdrowia publicznego. Dobrą komunikację charakteryzuje wiele zmiennych, ale na plan pierwszy wysuwa się wspólny język, wspólne słownictwo. I w tym kontekście, w celu rozwoju potencjału zdrowia publicznego w Polsce, niezbędne jest przede wszystkim ujednolicenie i uzgodnienie terminologii stosowanej w zdrowiu publicznym. Przy czym kwestia ta dotyczy nie tylko kilku wymienionych w tym artykule przykładów.

Po drugie, wszyscy partnerzy zaangażowani w działania zdrowia publicznego powinni działać synchronicznie, również w tym znaczeniu, aby posługiwać się pewnym wspólnym instrumentarium. Dlatego ważnym krokiem w rozwoju potencjału zdrowia publicznego powinno być stworzenie i udostępnienie 
stosownych narzędzi, schematów, standardów czy protokołów właściwych dla potrzeb planowania, wykonania, monitorowania i ewaluacji programów zdrowotnych, a także do sprawozdawczości z ich przebiegu i efektów. Łącznie stworzyłoby to szansę na zharmonizowanie wizji, celów, strategii i metod działania zdrowia publicznego.

Po trzecie, dla rozwoju potencjału zdrowia publicznego potrzebne są jeszcze klimat i zaangażowanie polityczne, wsparcie finansowe i techniczne, dobre zarządzanie, kreatywne mechanizmy podejmowania decyzji oraz umiejętności realizatorów.

\section{Bibliografia}

Acheson D., Public Health in England: The Report of the Committee of Inquiry into the Future Development of the Public Health Function, H.M. Stationery Office, London 1988.

Bernatowska E. i in. Szczepienia ochronne przeciwko Streptococcus pneumoniae u dzieci. Raport Grupy na rzecz Programu Szczepień Ochronnych w Polsce, Stowarzyszenie Parasol dla Życia, Warszawa, marzec 2016 r.

Broditsky L., How Language Shapes Thought The languages we speak affect our perceptions of the world, „Scientific American” February 2011, https://www.gwashingtonhs.org/ ourpages/auto/2013/10/23/68598699/sci-am-2011.pdf.

Brownson R.C., Gurney J.G., Land G.H., Evidence-based decision making in public health, „J Public Health Management Practice” 1999, t. 5, nr 5.

Bryant T., Raphael D., Schrecker T., Labonté R., Canada: A land of missed opportunity for addressing the social determinants of health, „Health Policy” 2010, t. 101, nr 1, doi: 10.1016/j.healthpol.2010.08.022.

Bunker J.P., The role of medical care in contributing to health improvements within societies, „International Journal of Epidemiology” 2001, t. 30, nr 6, https://doi.org/10.1093/ ije/30.6.1260.

Centers for Disease Control and Prevention, National Public Health Performance Standards Glossary, Version 3.0, http://www.astho.org/Accreditation/National-Public-Health-Performance-Standards-Version-3_0-Glossary/.

Cianciara D. i in., Diagnoza istniejacej organizacji i funkcjonowania systemu zdrowia publicznego w Polsce - rzeczywisty sposób działania systemu, t. I, Podsumowanie, Narodowy Instytut Zdrowia Publicznego - Państwowy Zakład Higieny, Warszawa 2017, http://bazawiedzy.pzh.gov.pl/nierownosci-w-zdrowiu.

Cianciara D. i in., Diagnoza istniejącej organizacji i funkcjonowania systemu zdrowia publicznego w Polsce - rzeczywisty sposób działania systemu, t. II, Narodowy Instytut Zdrowia Publicznego - Państwowy Zakład Higieny, Warszawa 2017, http://bazawiedzy.pzh.gov.pl/nierownosci-w-zdrowiu.

Davis R. $\mathrm{i}$ in., Theories of behaviour and behaviour change across the social and behavioral sciences: a scoping review, „Health Psychology Review” 2015, t. 9, nr 3, https://doi.1 0.1080/17437199.2014.941722. 
Dercz M., Izdebski H., Prawne aspekty organizacji i funkcjonowania systemu zdrowia publicznego $w$ Polsce. (Analiza prawa ustrojowego, materialnego i formalnego), raport sporzadzony w ramach poddziałania 1.2: „Diagnoza obecnej organizacji i funkcjonowania systemu zdrowia publicznego w Polsce", realizowanego w ramach Programu $P L$ 13: Ograniczenie społecznych nierówności w zdrowiu, współfinansowanego ze środków Norweskiego Mechanizmu Finansowego 2009-2014, Warszawa 2015, http:// bazawiedzy.pzh.gov.pl/nierownosci-w-zdrowiu.

Dutton D.J., Forest P.G., Kneebone R.D., Zwicker J.D., Effect of provincial spending on social services and health care on health outcomes in Canada: an observational longitudinal study, „CMAJ” 2018, t. 190, nr 3, doi:10.1503/cmaj.170132.

Evidence-Based Medicine Working Group, Evidence-based medicine. A new approach to teaching the practice of medicine, „JAMA” 1992, t. 268, nr 17.

GUS, Trwanie życia w 2017 r. Warszawa 2018.

Healthy People: The Surgeon General's Report on Health Promotion and Disease Prevention. U.S. Department of Health, Education, and Welfare, United States Public Health Service 1979, rozdz. 1.

Ho J.Y., Hendi A.S., Recent trends in life expectancy across high income countries: retrospective observational study, „BMJ” 2018, nr 362, https://doi.org/10.1136/bmj.k2562.

Kohatsu N.D., Robinson J.G., Torner J.C., Evidence-based public health: an evolving concept, „American Journal of Preventive Medicine” 2004, t. 27, nr 5.

Koplan J.P. i in., for the Consortium of Universities for Global Health Executive Board, Towards a common definition of global health, „Lancet” 2009, t. 373, nr 9679, https:// doi.org/10.1016/S0140-6736(09)60332-9.

Leowski J., Funkcje zdrowia publicznego, „Zdrowie Publiczne” 2001, t. 111.

Lianov L., Johnson M., Physician competencies for prescribing lifestyle medicine, „JAMA" 2010, t. 304, nr 2, doi: 10.1001/jama.2010.903.

Nosko J., O potrzebie ustawy o zdrowiu publicznym, „Zdrowie Publiczne” 2001, t. 111.

Nutbeam D., Health promotion glossary, „Health Promotion International” 1986, t. 1, nr 1, https://doi.org/10.1093/heapro/1.1.113

Nutbeam D., Health promotion glossary, WHO, Geneva 1998.

Ottawa Charter for health promotion, „Health Promotion International” 1986, t. 1, nr 4.

Raphael D., Health inequalities in Canada: current discourses and implications for public health action, „Critical Public Health” 2000, t. 10, nr 2.

Rdzany R., Krytyczna analiza lokalnych programów z zakresu profilaktyki chorób przewlektych oraz promocji zdrowia, przewidzianych do realizacji na szczeblu powiatów i gmin, zgłoszonych do Agencji Oceny Technologii Medycznych, Warszawa, maj 2015 r., http://bazawiedzy.pzh.gov.pl/nierownosci-w-zdrowiu.

Royal College of Physicians, Objectives of training in the specialty of public health and preventive medicine, 2014, http://www.royalcollege.ca/cs/groups/public/documents/ document/y2vk/mdaw/ edisp/tztest3rcpsced000887.pdf.

Rose G., Strategy of prevention: lessons from cardiovascular disease, „British Medical Journal (Clinical Research Ed.)" 1981, t. 282, nr 6279. 
Tarlov A.R., Public policy frameworks for improving population health, „Annals of the New York Academy of Sciences" 1999, t. 896.

The case for investing in public health. The strengthening public health services and capacity, WHO Regional Office for Europe, 2014.

The Tallinn Charter: Health Systems for Health and Wealth, WHO Regional Office for Europe, Copenhagen 2008.

Tugwell P., Robinson V., Grimshaw J., Santesso N., Systematic review and knowledge translation, „Bulletin of World Health Organization” 2006, t. 84, nr 8.

Tulchinsky T.H., Varavikova E.A., What is the „New Public Health”?, „Public Health Reviews" 2010, t. 32, nr 1, https://doi.org/10.1007/BF03391592.

Virchow R., Report on the typhus epidemic in Upper Silesia, „Archiv für Pathologishe Anatomie und Physiologie und für Klinische Medizin” 1848, t. II, nr 1-2 [za:] „Social Medicine" 2006, t. 1, nr 1.

WHO, European Action Plan for Strengthening Public Health Capacities and Services, WHO Regional Office for Europe, Copenhagen 2012.

WHO, Glossary of terms used in the „Health for All” series nr 1-8, WHO, Geneva 1984. WHO, Self-assessment tool for the evaluation of essential public health operations in the WHO European Region, WHO Regional Office for Europe, Copenhagen 2015.

\section{Akty prawne}

Ustawa z 27 sierpnia 2004 r. o świadczeniach opieki zdrowotnej finansowanych ze środków publicznych, Dz.U. nr 210, poz. 2135, ze zm.

Ustawa z 15 kwietnia 2011 r. o działalności leczniczej, Dz.U. nr 112, poz. 654, ze zm.

Ustawa z 11 września 2015 r. o zdrowiu publicznym, t.j. Dz.U. 2018, poz. 1492.

Rozporządzenie Rady Ministrów z 4 sierpnia 2016 r. w sprawie Narodowego Programu Zdrowia na lata 2016-2020, Dz.U. poz. 1492.

Rozporządzenie Ministra Zdrowia z 21 grudnia 2016 r. w sprawie rocznej informacji o zrealizowanych lub podjętych zadaniach z zakresu zdrowia publicznego, Dz.U. poz. 2216.

Rozporządzenie Ministra Zdrowia z 22 grudnia 2017 r. w sprawie wzoru programu polityki zdrowotnej, wzoru raportu końcowego z realizacji programu polityki zdrowotnej oraz sposobu sporządzenia projektu programu polityki zdrowotnej i raportu końcowego z realizacji programu polityki zdrowotnej, Dz.U. poz. 2476.

\section{Strony internetowe}

Projekt ustawy o zdrowiu publicznym. Projekt uzgodnienia, 28 marca 2015 r., https:// legislacja.rcl.gov.pl/docs//2/12270850/12281752/12281753/dokument156531.pdf.

OECD. Stat. Health expenditure and financing, http://stats.oecd.org/index. aspx?DataSetCode=HEALTH_STAT.

Http://www.programyrekomendowane.pl/. 